\title{
石灰窒素施用によるナタネの発芽障害
}

長江 春季・林原 清光・寺中 理明 (九州農試畑作部)

篠田 辰彦（海外技術協力事業団）藤丰 溥 (東海近畿農試)

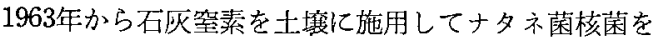
防除する試験を行ない，子のう盤発生を抑制する効果の あることを認めてきたが，1965年の試験で，それまで見 られなかった発牙障害（不発芽および発芽後約 2 週間く らい後に葉緣部から匞白色の壤死斑を生じ次第に茎が萎 调，枯死するものを含む）を認めたので，石灰窒素施用 の方法および施用後の条件がナタネの発芽障害に及ぼす 影響について試験を行なった。

\section{（1）石灰窒素の種類・施用法がナタネの発芽, 初期生育に及ぼす影響}

石灭窒素の種類：粉状（軍配印 $\mathrm{CaCN}_{2} 50 \%$ ），粗哱状 $\left(\mathrm{CaCN}_{2} 55 \% ， 3 \mathrm{~mm}\right.$ 方眼の網目を通り $1.5 \mathrm{~mm}$ 方眼の網目 に残るもの)の 2 種類を用いた。

施用法：土表面に均一に散布する表面施用と，均一に 散布後表首 $3 \mathrm{~cm}$ の土埕と温和する混層施用との二方法を 比較した。

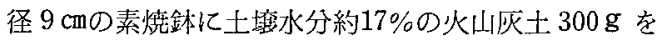
詰めて直ちに石灰窒素（粉状 $0.23 \mathrm{~g}$ ，粗砕状 $0.25 \mathrm{~g}$ ) を 施し 10 日閒 $25^{\circ} \mathrm{C}$ 定温器内に放置後吸上給水によって水 分を均一に保持させ，農林14号の種子を 1 鉢当り 50 精約 $5 \mathrm{~mm}$ の深さに播種した。播種後 7 日，17日，21日に発生 数を調查し，42日後にはいったん発芽後菱调枯死した苗 数を調査した。結果は第 1 表に示した。播種後 7 日で無 施用の標準区はほぼ全部が発牙するが，石灰窒素区は粗 砕状, 粉状とも極めて発芽が悪く, 特に粗㸴状の場合に はほとんど発芽しなかった。しかし播種21日後の調査で は粗碀状石灰空素の表面施用区を除けば大部分は発芽し た。発牙した幼植物が障害をうけ枯死した率は粉状施用 区では約 $25 \%$ ，粗砕状施用区では約40\%で粗砕状の方が 枯死率が高く，表面，混層両施用法での差は認められな かった。結局健全に生育した苗は粗研状石圧案素を表面

第 1 表 石灰窒素の種類, 施用法がナタネの発 牙, 初期生育におよぼす影留

\begin{tabular}{|c|c|c|c|c|c|}
\hline \multirow{2}{*}{\multicolumn{2}{|c|}{$\begin{array}{l}\text { 石灰窒蒵の種 } \\
\text { 類, 施用法 }\end{array}$}} & \multicolumn{2}{|c|}{ 発 芽 率 } & \multirow{4}{*}{\begin{tabular}{|c|}
$\begin{array}{c}\text { 発芽後 } \\
\text { 枯死率 }\end{array}$ \\
$\begin{array}{l}42.4 \% \\
44.4\end{array}$
\end{tabular}} & \multirow{4}{*}{$\frac{\text { 健全苗率 }}{2.3^{\%}}$} \\
\hline & & \multirow{3}{*}{ 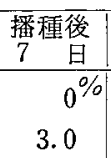 } & \multirow{3}{*}{$\begin{array}{c}21 \text { 日 } \\
4.0^{\%} \\
89.0\end{array}$} & & \\
\hline 粗础状 & 表 面 & & & & \\
\hline 相俨认 & 混 尿 & & & & \\
\hline \multirow{2}{*}{ 粉 状 } & 表 面 & 23.0 & 96.0 & 28.0 & 69.1 \\
\hline & 漉 凮 & 32.5 & 95.0 & 23.5 & 73.4 \\
\hline \multicolumn{2}{|l|}{ 䙞 } & 98.0 & 99.0 & 7.3 & 91.8 \\
\hline
\end{tabular}

に施用した場合が最も少なく，次いで粗砕状混層の場合 で, 粗砕状表面施用の障害が最も大きかった。

\section{（2）石灰窒素の施用量, 施用後の土墥水分がナタ ネの発芽，初期生育に及ぼす影蜂}

素焼剑に乾燥土 $300 \mathrm{~g}$ を詰め，粗砕状の 石灭窒素を $0.23 \mathrm{~g}(40 \mathrm{~kg} / 10 \mathrm{a}), 0.14 \mathrm{~g}(25 \mathrm{~kg} / 10 \mathrm{a})$ 表層 $3 \mathrm{~cm}$ までの 土坮と混和して直ちに乾，湿の処理を行なった。すなおち そのまま放置したものを乾燥区，吸上給水によって水分 を飽和させたものを湿潤区とし，各処理とも石圧窒素施 用後 10 日間は $25^{\circ} \mathrm{C} の$ 定温器内に㧍き, その後農林 14 号の 種子 50 粒を播種した。播種後は乾湿区とも一様に給水し て $18^{\circ} \mathrm{C}$ 定温器中に 5 日間おき, あとは室内に扔いた。 調查の時期，方法は(1)試験と同椂である。結果位第 2 表

第 2 表石灰窒素の施用量, 施用後 10 日間の土墥 第 2 表水分がナタネ種子の発芽, 初期生育に戈 よぼす影響

\begin{tabular}{|c|c|c|c|c|c|}
\hline \multirow{2}{*}{ 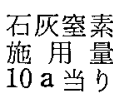 } & \multirow{2}{*}{ 土壤水分 } & \multicolumn{2}{|c|}{ 発芽率\% } & \multirow{2}{*}{$\begin{array}{c}\text { 発芽後 } \\
\text { 枯死率 } \\
\%\end{array}$} & \multirow{2}{*}{$\begin{array}{c}\text { 健全苗率 } \\
\%\end{array}$} \\
\hline & & 7 日目 & 21日目 & & \\
\hline \multirow{2}{*}{$40 \mathrm{~kg}$} & 乾 & 0 & 0 & - & 0 \\
\hline & 湿 & 3.0 & 89.0 & 44.4 & 49.5 \\
\hline \multirow[t]{2}{*}{$25 \mathrm{~kg}$} & 乾 & 0.5 & 0.5 & 30.8 & 0.2 \\
\hline & 湿 & 40.0 & 99.5 & 13.6 & 86.0 \\
\hline \multirow{2}{*}{$\begin{array}{c}0 \\
\text { (標準) }\end{array}$} & 乾 & 96.0 & 99.5 & 4.0 & 95.2 \\
\hline & 湿 & 98.0 & 99.5 & 7.3 & 92.2 \\
\hline
\end{tabular}

のとおりであった。施用量 $40 \mathrm{~kg} / 10 \mathrm{a}$ と $25 \mathrm{~kg} / 10 \mathrm{a} て ゙ は$ 前 者の方が 7 日目の発芽率が低く，発芽後の苗の枯死率が 高かった。土淁水分の差は発芽障害に大きな影響があ り，乾燥条件では $40 \mathrm{~kg}, 25 \mathrm{~kg}$ ともほとんど発芽しなかっ た。10日間水分飽和の土塆では発芽の遅れはみられた が，21日目には大部分の種子が発芽した。また発芽後の 苗の枯死乘已低加った。

(1)，(2)両試験からみると石灰空薪施用によるナタネの 発芽障害は一般に粗砕状のものを表面に散布施用し，施 用後の土壤水分の少ないときほど起こりやすく，なかで も最も大きな影響をもつのは土淁水分で，施用後乾燥が 続く時障害が大きい。

\section{（3）石灰窒素の分解生成分が発芽に及ぼす影響}

石灰窒素は土簀に施用されたあとシアナミドを経て尿 素，炭酸アンモンなどに分解し，ある場合にはシアナる ドが重合してシシアノジアドの形で比較的安定に保た 
第 3 表 石灰等琹の分解生成分がナタネ種子の発芽率におよぼす影響（3区平均）

\begin{tabular}{|c|c|c|c|c|c|c|c|c|c|}
\hline 薬 品 & $\mathrm{CaC}$ & & $\mathrm{CNI}$ & $\mathrm{NH}_{2}$ & $(\mathrm{CN}$ & $\left(\mathrm{H}_{2}\right)_{2}$ & $\mathrm{CO}\left(\mathrm{NH}_{2}\right)_{2}$ & $\mathrm{NH}_{4} \mathrm{NO}_{3}$ & $\mathrm{Ca}(\mathrm{OH})_{2}$ \\
\hline 濃 度 & 1966年 & 1967年 & 1966 & 1967 & 1966 & 1967 & 1966 & 1966 & 1966 \\
\hline $100 \mathrm{ppm}$ & $100 \%$ & $99.3^{\%}$ & $99.3^{\%}$ & $99.3^{\%}$ & $100 \%$ & $100 \%$ & $100 \%$ & $10 \%$ & $99.3^{\%}$ \\
\hline 1,000 & 100 & 11.0 & 99.3 & 99.3 & 100 & 100 & 100 & 99.3 & 100 \\
\hline 5,000 & 100 & 0 & 100 & 100 & 100 & 100 & 100 & 99.3 & 100 \\
\hline 10,000 & 100 & 0 & 100 & 99.3 & 100 & 100 & 98.6 & 100 & 100 \\
\hline 25,000 & - & 0 & - & 0 & - & 0 & - & - & - \\
\hline 50,000 & 92.0 & 0 & 0 & 0 & - & 0 & 99.3 & 100 & 100 \\
\hline
\end{tabular}

一は試験を行なわなかったもの，または欠測値

れることがあるとされている。そこでナタネの発芽障害 がこれら分解生成分のいずれによって主に起こるものか を知ろうとして実験を行なった。

シアナミド, シシアノジアミド,尿素, 硝酸アンモニア, 水酸化カルシウムおよびカルシウムアミドの 6 種の試薬 を $100,1,000,5,000,10,000,25,000,50,000 \mathrm{ppm}$ に調製し, 径 $9 \mathrm{~cm}$ のペトリ皿に滤紙を敷き各液を $20 \mathrm{ml}$ (1966年), 10ml (1967年) 注入したものを発芽床とし,農林 14 号の種子50粒を置休した。1 処理 3 ペトリ田ずつを供 試し, 置床後直ち江約 $20^{\circ} \mathrm{C}$ 定温器内に入れた。処理後 4，7 日に発芽数を調查し，7日目には生育状況を調べ た。第 3 表は1966年, 1967 年の両年に行なった試験の 7 日目の発䓉率を示したものである。尿素, 硝酸アンモ二 ア，水酸化カルシウムはこの試験の嶩度範围では発芽に 全く影響が認められなかった。シアナミドシシシアノジ アミドは 10,000ppm までの溊度ではナタネの発芽はほ とんど100\%を示したが，25,000ppm 以上の濃度で急激 な発牙障害がみられた。10,000ppm では播種後7日の 観祭では娃植物がやや黄色を帯び，また 25,000 ppmで は発芽には至らなかったが種皮の破れた種子が10〜20\% みら机た。5, 000ppm では植物体の緑色は無処理と同様 であったので, シアナミド, シシアノジアミドによる発第 障害はシャーレ試験では 10,000ppm〜25,000ppm の間 と考えられる。カルシウムシアナミドは, 1966年と1967年 の結果が非常に隔っていてどのくらいの濃度が発芽阻害 の限界か定められなかった。また両年の結果の不一致の
原因も明らかでない。これらの結果から，石灰窑素施用に よるナタネの発芽障害は石灰窒素の主成分であるカルシ ウムシアナミドそのものかシアナミド, ジシアノジミ ドなど分解生成分の複合によって起こるものと思われる。

（4）石灰窒素の種類, 施用法, 土壤の水分条件の

\section{相違がその分解速度に及ぼす影響}

(1)，(2)の試験で石灰空素の種類, 施用法, 土境水分条件 がナタネの発芽に大きな影響を及ぼすことを知り，(3)試 験で石灰窒素の分解生成分が発芽に影響を及ぼすことを 知ったので，石灰空素の種類，施用法，士燷水分の相違が 石灰窒素の分解侸影響を及ぼ，その結果発苏障害の差 異を示すのではないかと考えて土壌中の石灰等素の分解 をシアナミド態公素の消長を指標にして検討した。当場 火山灰土を $3 \mathrm{~mm}$ 方腿の金網で穊い，風乾したもの70 $\mathrm{g}$ を $200 \mathrm{~m}$ 入りのフラスコに入れ，粉状 $0.154 \mathrm{~g}$, 粗硈状 0.14 $\mathrm{g}$ の石灰空素を表面，混層施用し，乾燥土区とした。同 様に処理したものに25mlの蒸留水を加えたものを湿潤区 とした。処理後は $18^{\circ} \mathrm{C}$ 定温器内に分析日までおいた。 $2 \%$ 酶酸液 $100 \mathrm{~m} \ell$ で土壤を振蕰ろ過し, 抽出溶液中のシ アナミドの量を硝酸銀法（肥料分析法「現行法第 $6 \mathrm{~F}$ 」) に準じて行なった。結果は第4表のとおりであった。1 フラスコ中に投与リた石灰空菜量から理論的に計算され るシアナミド態空素の量は約 26〜27m/ 1 フラスコであ るから粗砕状の石灰空素を乾燥土壤の表面においた場合 には最も分解が遅く，20日後でも約 $85 \%$ が残存している ことになる。粗砕状は粉状に比べて分解が遅く, 乾燥,

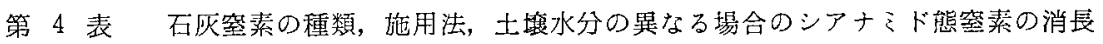

\begin{tabular}{|c|c|c|c|c|c|c|c|c|}
\hline \multirow{2}{*}{$\begin{array}{l}\text { 石扊公秦 } \\
\text { の種 } \\
\end{array}$} & \multirow{2}{*}{\multicolumn{2}{|c|}{ 播種後日数水分 }} & \multirow{2}{*}{$\begin{array}{r}\text { 乾 } \\
3 \text { 日 } \\
\end{array}$} & \multicolumn{2}{|r|}{ 燥 } & \multirow{2}{*}{$\frac{\text { 湿 }}{3 \text { 日 }}$} & \multicolumn{2}{|c|}{ 潤 } \\
\hline & & & & 15日 & 20日 & & $15 \mathrm{~F}$ & 20 日 \\
\hline \multirow{2}{*}{ 粉 状 } & 表 & 面 & $15.39 \mathrm{mg}$ & $10.41 \mathrm{mg}$ & $7.46 \mathrm{mg}$ & $14.68 \mathrm{mg}$ & $2.84 \mathrm{mg}$ & oug \\
\hline & 混 & 層 & 9.31 & 0.97 & 0 & 14.97 & 0.68 & 0 \\
\hline \multirow{2}{*}{ 粗研状 } & 表 & 面 & 25.82 & 24.77 & 22.90 & 20.93 & 6.91 & 0 \\
\hline & 混 & 屬 & 22.41 & 20.20 & 13.61 & 17.61 & 3.78 & 0 \\
\hline
\end{tabular}


混畨の場合でも 20 日後に約 $1 / 2$ 量のシアナミド態空素が検 出された。土境中の水分も分解に大きな影響があり粉 状，混首区を除いては乾湿画処理区の間には著しい相違 がみられた。また表面施用，混層施用の間でも分解の遅

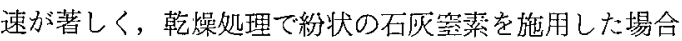
に最も雨処理間の差は明暸であった。

\section{（5）土中のシアナミド態窒素の量とナタネ発芽と の関係}

(4)実験に用いたフラスコの一部をとり，これに農林 14 号の種子をまいて発考を調査し，土袞中のシアナミド態 窒素舅とナタネの発芽との関係を示したのが第 1 図であ る。この結果によれば土瓖中のシアナミド熊窒素量が投 与石灰䇪素量加理論的に計算される約半量以下に低下 すると（ほぼ10〜 13mg)，ナタネの発芽は急増する傾向が みられた。シアナミド態空素の量が 10〜 13mg/ 1 フラス コ以上の時は発芽は顕著に抑えられ，活とんどが発芽率 0〜20\%の間にばらつき，シアナミド態窒素の量と発㐧 率との間には直線関係は㤎めら机なかった。つまり石庅 䇪素の分解が半分程度進むまでは非常に大きな発芽障害

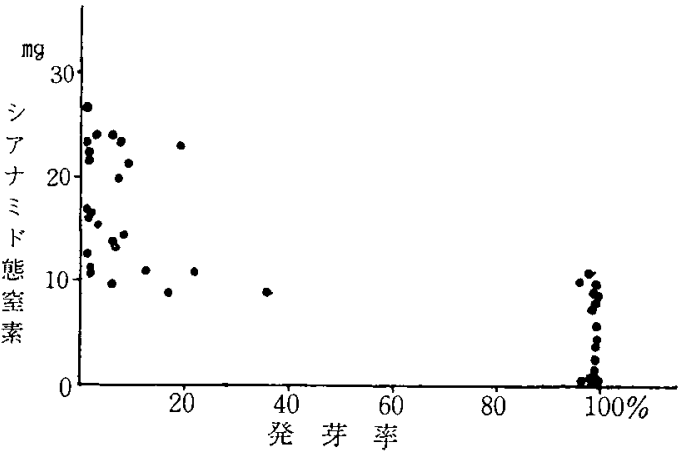

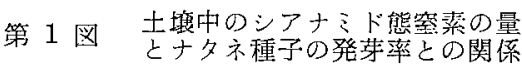

があるが，それ以上分解が進めばほとんど発牙には影響 がないと考えられる。

\section{参考 交 献}

1) 奥田東住(1967)：土墥肥料ハンドブック，664 pp. 2）三井進午ほか(1962)：土肥誌，33，537〜 542，543〜 5473 ) 中村雄監修 (1966)：肥料分析法，372 pp. 4) 米田茂男 (1937)：土肥烃，11，447〜454

\section{石灰窒素の分解生成物がナタネ菌核病菌の子のう盤形成におよぼす影響}

\section{長江 春季・木原 清光・寺中 \\ 理明（九州農業試験場畑作部）}

篠田 辰彦（海外技術協力事業団） 藤井＼cjkstart溥（東海近畿農業試験場）

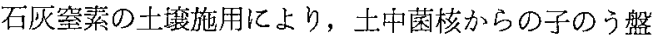
形成が抑制されたことが認められその実用性が検討され つつある。このような石灰窒素の効果は, 殺菌作用によ るものではなく，静菌的作用であることを認めたが，そ の後ひきつずいて石灰空素の分解生成物中のどのような ものによる作用かという点について検討を加えた。

石灭空素の土墡中に扮ける分解についてはこれまで多 数の研究があり，次のような変化を経て Ammonia に なるものとされている。

$$
\begin{aligned}
& \mathrm{CaCN}_{2}+2 \mathrm{H}_{2} \mathrm{O}=\mathrm{CNNH}_{2}+\mathrm{Ca}(\mathrm{OH})_{2} \\
& \mathrm{CNNH}_{2}+\mathrm{H}_{2} \mathrm{O}=\mathrm{CO}\left(\mathrm{NH}_{2}\right)_{2} \ldots \ldots \ldots \ldots \\
& \mathrm{CO}\left(\mathrm{NH}_{2}\right)_{2}+2 \mathrm{H}_{2} \mathrm{O}=\left(\mathrm{NH}_{4}\right)_{2} \mathrm{CO}_{3} \ldots \ldots
\end{aligned}
$$

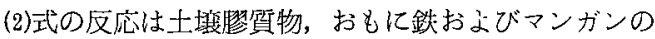
含水酸化物の触某作用によっておこなわれ，土㙯膠質物 との接触が密なほど分解がはやく,膠質物がとぼしい土, 例えば仯土などでは分解がおそい。(3)式の反忘は微生物 の作用によりおこなわれる。通常(3)式の反応速度は(2)式

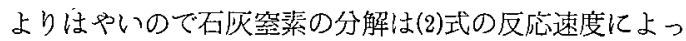
て左右される。(2)式の反応が㧈そいばあいには Cyanamide が2 分子重合して Dicyanodiamide を生ずること がある。

$$
2 \mathrm{CNNH}_{2}=\left(\mathrm{CNNH}_{2}\right)_{2}
$$

この Dicyanodiamide は畑条件では分解がおそく硝 酸化成作用を抑制するとされている。 $\left(\mathrm{NH}_{4}\right)_{2} \mathrm{CO}_{3}$ は土 壇中でさらに $\mathrm{NH}_{4} \mathrm{NO}_{3}$ になる。

この分解過程のほ加 Cyanamide の加水分解は条件 によってはさらに複雑となり一部グアニル尿素, グア二 ジなどが生成されることのあることも知られている。

ここではこ扎ら石灭空素の分解過程に括ける生成物の おもなものを刘象とした。

\section{試験 方 法}

直径 $9 \mathrm{~cm}$ のペトリ血に火山灭士（土壤水分約 $34 \%$ ） 35 $\mathrm{g}$ を詰めたもの，こ扎を高圧殺菌 $\left(120^{\circ} \mathrm{C}\right.$ ３0分間）した もの, および $5 \sim 7 \mathrm{~mm}$ 平方に細切したろ紙（東洋，No. 131 直径 $15 \mathrm{~cm}$ のの一枚半分）を詰めたものの三種のベ 一スを用い, ナタネ荤葉培地で $24^{\circ} \mathrm{C} 〜 30$ 日間培等したナ タネ菌核病菌 (単胞子分離菌) の培意菌核を 1 ペトリ皿 当り15個ずつ1966年12月20日に置床した。あらかじめろ 紙区に蒸貿水を $10 \mathrm{ml} /$ ペトリ皿ずつ一様に供給し，土塆 区との水分差をすくなくした後ろ紙, 土堘区とも $\mathrm{CaCN}_{2}$ $100 \mathrm{mg}$ /ペトリ且を基淮量とし，これが分解して生ずる 